\title{
Tectonic Proteins Are Important Players in Non-Motile Ciliopathies
}

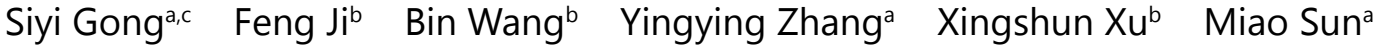 \\ aInstitute for Fetology, the First Affiliated Hospital of Soochow University, Suzhou, 'Institute of \\ Neuroscience, Soochow University, Suzhou, 'Division of Clinical Medicine, Soochow University, Suzhou, \\ China
}

\section{Key Words}

Cilia • Tectonic proteins • Ciliogenesis $•$ Sonic Hedgehog signaling pathway • Ciliopathies

\begin{abstract}
Primary cilium is a ubiquitous, tiny organelle on the apex of the mammalian cells. Non-motile (primary) ciliopathies are diseases caused by the dysfunction of the primary cilium and they are characterized by diverse clinical and genetic heterogeneity. To date, nearly 200 genes have been shown to be associated with primary ciliopathies. Among them, tectonic genes are the important causative genes of ciliopathies. Tectonic proteins including TCTN1, TCTN2, and TCTN3 are important component proteins residing at the transition zone of cilia. Indeed, many ciliopathies have been reported to involve tectonics mutations, highlighting a pivotal role for tectonic proteins in ciliary functions. However, the specific functions of tectonic proteins remain largely enigmatic. Herein, we discuss the recent advances on the localization and structure of tectonic proteins and the functions of tectonic proteins. The increasing line of evidences demonstrates that tectonic proteins are required for ciliogenesis and regulate ciliary membrane composition. More importantly, Tectonic proteins play a vital role in the regulation of the Sonic Hedgehog (Shh) pathway; Tectonic deficient mice show the Shh pathway-related developmental defects. Tectonic proteins share similar functions including neural patterning and Gli3 processing but also each has a unique and indispensable role in the ciliogenesis and signaling pathways. At the same time, the mutations of tectonic genes are the causes of a serial of primary ciliopathies including Meckel-Gruber syndrome, Oral-facial-digital syndrome, and Joubert syndrome. Therefore, full understanding of functions of tectonic proteins will help to crack ciliopathies and improve life quality of patients by future gene therapy.
\end{abstract}

\begin{tabular}{ll}
\hline Miao Sun, PhD & Institute for Fetology, the First Affiliated Hospital of Soochow University \\
& Suzhou, 215006 (China) \\
Tel. 86-512-67781973, E-Mail miaosunsuda@163.com
\end{tabular}




\section{Cellular Physiology Cell Physiol Biochem 2018;50:398-409 \begin{tabular}{l|l|l} 
DOI: 10.1159/000494017 & a 2018 The Author(s). Published by S. Karger AG, Basel \\
www.karger.com/cpb
\end{tabular} \\ Gong et al.: The Role of Tectonic Proteins in Ciliopathies}

\section{Introduction}

Non-motile ciliopathies is a group of diseases that arise from the dysfunction of a tiny and immotile structure called primary cilium, including polycystic renal diseases, Joubert syndrome, Oro-facial-digital syndrome, Meckel syndrome, Bardet-Biedl syndrome, Acrocallosal syndrome, Hydrolethalus syndrome, Pallister-Hall syndrome, and Greig Cephalopolysyndactyly syndromes [1]. As the primary cilia present on almost each mammalian cell, non-motile ciliopathies involve multiple systems and organs and thus exhibit appreciable clinical heterogeneities. Although more than 100 genes that are associated with ciliopathies have been identified [2], mutations in one certain gene can induce one or more phenotypes in multiple systems. Therefore, the complexity of the non-motile ciliopathies renders diagnoses and treatments extremely daunting. In the past few decades, due to the great significance of cilia in multiple organs and systems, non-motile ciliopathies gained more attentions. Here, we will briefly review the structure of cilia and then focus on the functions of cilia structural proteins--tectonics and tectonics-related ciliopathies.

\section{Primary cilia}

Cilium is a microtubule-based, antenna-like structure on the apical surface of cells during G0/G1 phase [3]. Under the electron microscope, each cilium 'hub' can be divided into the basal body, the transition zone, and the axoneme (Fig. 1). The basal body resides at the bottom of the cilia, which is originally formed by the mother centriole and migrates to the apical surface of the cell after certain transformations [4-6]. The basal body is composed of 9 circularly arranged triplets and distal appendages that connect with the cellular membrane $[7,8]$. The triplets contain three kinds of fibers: A, B, and C fibers. A and B fibers are made up of 13 and 10 tubulins respectively, grow and extend to form part of axonemes, while $C$ fiber is short fiber and limited at the transition zone $[9,10]$. The transition zone connects the distal

Fig. 1. Schematic structure of cilia. Cilia originate from a basal body, which is composed of nine triplet centrioles and distal appendages. Distal appendages (also known as transition fibers) are tied to the ciliary membrane. Transition zone bridges the basal body and the axonemes and connects to the membrane via the Y-linkers. Axonemes mainly consist of doublet microtubules. Usually, in primary cilia, which are immotile, they present a ' $9+0$ ' pattern, which means

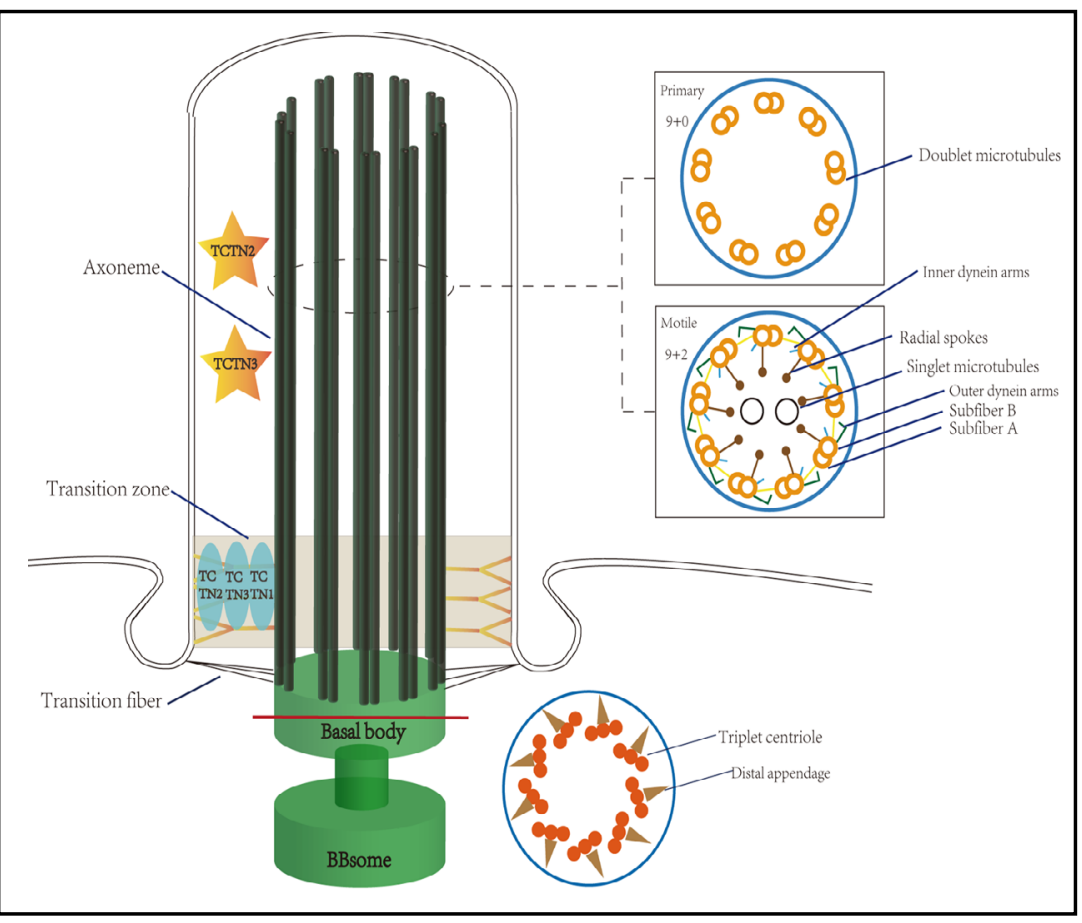
there are 9 doublet microtubules. While motile cilia have 9 doublet microtubules and 2 singlet microtubules, thus representing the '9+2' pattern. The dynein arms and radial spokes are responsible for the motility. 


\section{Cellular Physiology Cell Physiol Biochem 2018;50:398-409

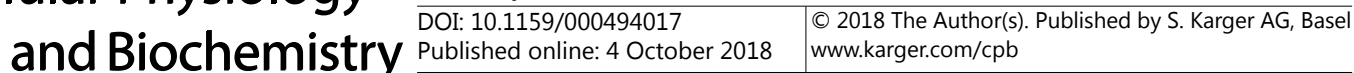

Gong et al.: The Role of Tectonic Proteins in Ciliopathies

end of basal body and the proximal region of the axonemes by using the Y-linkers from the axoneme to the ciliary membrane. The axoneme possesses 9 peripheral doublets with or without 2 central singletons. Typically, motile cilia usually have a ' $9+2$ ' microtubule pattern with the presence of radial spokes, dynein arms and nexin links; however, non-motile cilia have a ' $9+0$ ' microtubule pattern without two central microtubules and dynein arms that are responsible for mobility in motile cilia [11]. Nevertheless, there are some exceptions, for examples, nodal cilia with a ' $9+0$ ' microtubule pattern are motile because they have dynein arms [12]; On the contrary, kinocilia have a ' $9+2$ ' microtubule pattern, but they are the nonmotile cilia $[13,14]$.

Motile cilia and non-motile cilia (primary cilia) have different functions. On the surface of the airway, motile cilia facilitate the fluid movement in the airway, for instance, on the surface of the fallopian tubes, motile cilia move ovum from the ovary to the uterus [15]. However, primary cilia have no movement functions, but they, meanwhile, are able to receive signals from the outside and transduct signals in almost each mammalian cell [16]. Several developmental pathways, such as the Sonic hedgehog (Shh), Wnt, fibroblast growth factor, platelet-derived growth factor receptor $\alpha$, Notch, and Hippo pathways, depend heavily on the functions of primary cilia for signaling transduction [17-19]. Therefore, the dysfunction of certain proteins in cilia causes the altered functions of cilia and influences the transduction of these signaling pathways, resulting in different ciliopathies. Due to the ubiquitous existence and the indispensable role for various signaling transduction, primary cilia have been considered to have critical roles and are involved in the pathogenesis of the non-motile ciliopathies [2]. In this review, we focus on the main functions of tectonic proteins in primary cilia and tectonic proteins-related ciliopathies.

\section{Location and structure of Tectonic proteins}

Tectonic (TCTN) family is a group of proteins residing at the transition zone of a cilium, including TCTN1, TCTN2, and TCTN3. TCTN1 is the first tectonic protein to be found to play an important role in the neural tube patterning by mediating the Hedgehog pathway [20]. Subsequently, other tectonic family members such as TCTN2 and TCTN3 were uncovered by genomic database searching [20]. Many studies also demonstrated that TCTN1, TCTN2 and TCNT3 act as the regulators of the Hedgehog signaling pathway [20-22]. So far, 24 cases of non-motile ciliopathies have been reported to be relevant with mutations in tectonic genes [21-29]. Therefore, the discovery of Tectonic family has expanded the spectrum of the nonmotile ciliopathy genes and provided an opportunity for people to gain better understanding of the underlying molecular pathogenesis of ciliary defects. However, the roles of this protein family in non-motile ciliopathies remain elusive.

All tectonic proteins locate to the transition zone as shown in Fig. 1, while TCTN2 and TCTN3 also reside at the cilium proper [24]. TCTN2 occupies the outer compartment of the transition zone and the widest space compared to the other transition zone proteins [30]. A study showed that TCTN2, TMEM67, MKS1 and RPGRIPIL are at the same axial level in the transition zone compared with the average axial distance from other transition zone proteins to Centrin 2, which is a BBsome protein [30]. Additionally, the subdiffration imaging of TCTN2 indicated its subdivision of the intensity peaks into the cilium proper; which is consistent with the previous experiments done by Garcia-Gonzalo [24]. Unfortunately, data about the specific location of TCTN1 and TCTN3 within transition zone haven't been reported yet.

Human TCTN1 gene spans $35.4 \mathrm{~kb}$ in a region of human chromosome 12. Except for a N-terminal signaling peptide, the functions of other domains of TCTN1 protein are still unknown [20]. Human TCTN2 gene locates to $12 \mathrm{q} 24.31$ and encodes a 77-kDa protein incorporating a signal peptide at the first 25 amino acids and a carboxyl-terminal transmembrane domain that is anticipated to be a secreted and membrane protein [23]. 


\begin{tabular}{|c|c|c|}
\hline \multirow{2}{*}{$\begin{array}{l}\text { Cellular Physiology } \\
\text { and Biochemistry }\end{array}$} & \multicolumn{2}{|c|}{ Cell Physiol Biochem 2018;50:398-409 } \\
\hline & $\begin{array}{l}\text { DOI: 10.1159/000494017 } \\
\text { Published online: } 4 \text { October } 2018\end{array}$ & $\begin{array}{l}\text { O } 2018 \text { The Author(s). Published by S. Karger AG, Basel } \\
\text { www.karger.com/cpb }\end{array}$ \\
\hline
\end{tabular}

Human TCTN3 gene extends $30.7 \mathrm{~kb}$ on human chromosome 10. More information about three tectonic genes and proteins in Human and mice is summarized in Table 1.

\section{Tectonic proteins regulate ciliary membrane composition}

Tectonic proteins are showed to regulate the protein composition of the ciliary membrane $[24,31]$. Some proteins that locate to the primary cilia such as adenylyl cyclase 3 (AC3) and polycystic kidney disease 2 (PKD2) are lost or reduced in Tctn1\% and Tctn2\% mice or mutant mouse embryonic fibroblasts (MEFs) [24]. Smoothened (Smo), a seven-trans-membrane protein involving in the SHH signaling pathway, shows markedly reduction in the cilia of $\operatorname{Tctn} 1 \%, \operatorname{Tctn} 2 \%$, or mutant MEFs [24]. In addition, those mutant MEFs also display reduced ciliary localization of ADP-ribosylation factor-like protein 13B (Arl13b)[24]. As for TCTN3, AC3, Smo, and Arl13b are barely detected in the cilia of mutant MEFs [31]. Taken together, three TCTN proteins are essential for the successful transportation of proteins into the cilia.

\section{Tectonic proteins are required for ciliogenesis}

Tectonic proteins are also required in the ciliogenesis in a tissue-dependent manner [21, $24,31]$. This is partly explained by the fact that three TCTN proteins are of vital importance for the effective trafficking of those proteins that must be imported into the cilia and are required for the development of the cilia [32, 33]. In Tctn1, Tctn2 and Tctn3 mutant mouse embryos, the number of the cilia is significantly reduced in different tissues, suggesting that tectonic proteins are required for the ciliogenesis in a tissue-dependent manner [21, 24, 31]. Cilia are lost in nodes and neural tubes in Tctn1\% and Tctn $2^{\%}$ mouse embryos, but cilia are present in notochord, early gut epithelium, perineural mesenchyme, and limb bud mesenchyme in Tctn $1 \%$ embryos; while in Tctn $2 \%$ mice, limb bud mesenchyme displays decreased number of cilia and perineural mesenchymal cells lack cilia $[21,24]$. Tctn3 $\%$ embryos show significantly reduced numbers of cilia in the neural epithelia of the neural tube and mesencephalic vesicle, perineural tube, and notochord [31]. The results above suggest that the tectonic proteins are fundamental for the ciliogenesis in a tissue-dependent way (summarized in Table 2). In addition, MEFs with mutant TCTN proteins also exhibit decreased number of cilia or

Table 1. Basic information of the three tectonic genes and proteins

\begin{tabular}{lccccc}
\hline Gene /Protein & Charactors & Species & TCTN1 & TCTN2 & TCTN3 \\
\hline \multirow{3}{*}{ Gene } & Chromosome & Human & $12 \mathrm{q} 24.11$ & $12 \mathrm{q} 24.31$ & $10 \mathrm{q} 24.1$ \\
& & Mouse & 5 & 5 & 19 \\
& Size $(\mathrm{kb})$ & Human & 35.4 & 37.3 & 30.7 \\
& Exon & Mouse & 4.1 & 2.7 & 2.7 \\
& Human & 19 & 18 & 14 \\
& Mouse & 14 & 18 & 13 \\
Protein & & & & \\
& Molecular weight(kDa) & & 63 & 77 & $50 / 66$ \\
& DUF1619 & & + & + & + \\
& Carboxy-terminal transmembrane domain & & - & + & + \\
& Isoform & & 9 & 2 & 2 \\
\hline
\end{tabular}

Table 2. Various phenotypes in animal models of tectonic mutants

\begin{tabular}{|c|c|c|c|c|c|c|c|}
\hline Mutants & $\begin{array}{l}\text { Embryonically } \\
\text { lethality }\end{array}$ & Cilia & CNS & Eyes & $\begin{array}{l}\text { Cardiovascular } \\
\text { system }\end{array}$ & $\begin{array}{l}\text { Alimentary } \\
\text { system }\end{array}$ & Extremities \\
\hline $\begin{array}{l}\text { TCTN1 } \\
\text { mutant }\end{array}$ & Present & $\begin{array}{l}\text { Lost in nodes and neural tubes, } \\
\text { present in notochord, early gut } \\
\text { epithelium, perineural mesenchyme } \\
\text { and limb bud mesenchyme }\end{array}$ & $\begin{array}{l}\text { Holoprosencephaly, } \\
\text { heterotaxia }\end{array}$ & Microphthalmia & N/A & $\mathrm{N} / \mathrm{A}$ & $\begin{array}{l}\text { Hindlimb } \\
\text { polydactyly }\end{array}$ \\
\hline $\begin{array}{l}\text { TCTN2 } \\
\text { mutant }\end{array}$ & N/A & $\begin{array}{l}\text { Lost in nodes, neural tubes and } \\
\text { perineural mesenchymal cells, } \\
\text { decrease in limb bud } \\
\text { mesenchyme( on a mixed 129/B16 } \\
\text { background) }\end{array}$ & $\begin{array}{l}\text { Holoprosencephaly, } \\
\text { heterotaxia, cleft palate }\end{array}$ & Microphthalmia & $\begin{array}{l}\text { Ventricular septal } \\
\text { defects }\end{array}$ & $\begin{array}{l}\text { Right-sided } \\
\text { stomach }\end{array}$ & $\begin{array}{l}\text { Hindlimb } \\
\text { polydactyly }\end{array}$ \\
\hline $\begin{array}{l}\text { TCTN3 } \\
\text { mutant }\end{array}$ & Present & $\begin{array}{l}\text { Significantly reduced in the neural } \\
\text { epithelia in the neural tube and } \\
\text { mesencephalic vesicle, perineural } \\
\text { tube and notochord }\end{array}$ & Holoprosencephaly & Microphthalmia & $\begin{array}{c}\text { Some with the heart } \\
\text { that turn in a right } \\
\text { orientation }\end{array}$ & $\mathrm{N} / \mathrm{A}$ & $\begin{array}{l}\text { Polydactyly, } \\
\text { edema on the } \\
\text { back of the upper } \\
\text { body }\end{array}$ \\
\hline
\end{tabular}


completely loss of cilia $[21,24,31]$. Therefore, these evidences demonstrate that tectonic proteins are required for ciliogenesis.

\section{Tectonic proteins play a vital role in the regulation of the Sonic Hedgehog (Shh) pathway}

Tectonic Knockout mice show the Shh pathway-related developmental defects

The Sonic Hedgehog (Shh) signaling pathway is one of the most important pathways in the brain development [34-40]. Different members of tectonic proteins display distinct roles in regulating the Shh pathway because the Shh pathway-related developmental abnormalies are found in mice with tectonics deletion. Tctn1 null mice present holoprosencephaly, heterotaxia, microphthalmia, and hindlimb polydactyly that resemble the phenotypes of mice with Shh signaling defects $[20,41]$. Except for these characteristics in Tctn $1^{-/}$mice, additional phenotypes including cleft palate, ventricular septal defects and right-sided stomach are present in Tctn2\% mice [21]. Tctn $3^{\%}$ mice display edema on the back of the upper body, right-oriented heart [31] as well as holoprosencephaly, microphthalmia [42] and polydactyly that have been reported to have a strong association with the altered Shh signaling pathway $[43,44]$.

The downstream signals of the Shh pathway are changed in Tectonic mutant mice

Some molecular markers regulated by the Shh signaling are altered in the mutant mouse embryos, which further supports the statement that TCTN proteins are crucial in mediating the Shh pathway [20, 21, 31]. Loss of floor plate and V3 interneurons in the Tctn1\% and Tctn2\% mice marked the reduction of FoxA2 and Nkx2.2 expression respectively in the Shh signaling pathway $[20,21]$. Islet1/2-positive motor neurons are found to have a significant reduction in Tctn $1 \%$ and Tctn $2 \%$ mice. Pax6, a molecule suppressed by the Shh signal, is widely distributed in both Tctn $1 \%$ and Tctn2\%-mice [20, 21]. However, Tctn3 null mice exhibit normal Pax6, Pax7, and Hb9 expression levels, although FoxA2 level is not detected in Tctn31- embryos [31]. Taken together, we assume that TCTN proteins display distinct roles in the Shh signaling pathway. In addition, the significant reduction of Gli1 and Ptch, common transcriptional targets of the Shh signaling, is found in the three mutant embryos or cells, indicating that TCTN proteins share some common effects on the Shh signaling [20-22, 31].

Tectonic proteins conservatively regulate the Gli3 processing

Gli3 is another important transcriptional target of the Shh signaling [31]. Tectonic proteins are functionally conserved in the Gli3 processing. When Tctn1 is absent, the cleaved repressor form Gli3R increases; whileTctn2\% embryos exhibit increased number of full-length Gli3[21]. Similarly, TCTN3 mutated fibroblasts exhibit decreased amounts of full-length unprocessed GLI3 protein [22]. The different effects of tectonic proteins on Gli3 processing indicate that tectonic family members have some overlapping and complementary roles in the Shh signaling. Therefore, evidences indicate that TCTN1, TCTN2, and TCTN3 share obvious similarities in their conserved functions such as neural patterning and Gli3 processing [31].

How tectonic proteins directly regulate the Shh signal pathway remains unknown

TCTN1 is considered to be epistatic to Ptch, Rab23, and Smo [20]. Ptch is a 12-transmembrane protein receptor. When Ptch binds to Shh protein in the cell membrane, the Shh pathway is activated [45]. Thus, mutant TCTN1 blocks the binding of Ptch1 receptor to Shh protein and leads to the inactivation of the Shh pathway. Under most circumstances, free Ptch1 receptor constrains Smo receptor that is a seven-transmembrane protein. Once Shh protein binds with Ptch1, a biological complex is formed and then undocks the ciliary membrane, which further promotes the activation of the Smo protein. With the activation of Smo receptor, the phosphorylation of Gli transcription factor is ceased, rendering the intact 
Gli protein to combine with Sufu (suppressor of fused), a repressor of Shh pathway. Two proteins form a complex, translocate to the tip of the cilia and disassociate with each other. The Gli proteins act as a transcriptional factor upon entering the nucleus, and promote the transcription of some essential genes encoding the proteins in the Shh signaling pathway, thus leading to the development of the neural tube [46]. Therefore, mutant TCTN1 can hinder the activation of Smo protein and inhibit the entry of Gli protein into the nucleus and the transcriptions of the Shh pathway-related proteins. More evidences show that the significant reduction of Ptch and Gli1 occurs in all tectonic mutant embryonic mice and MEFs [20-22], which indicates tectonic proteins act at the upstream of Ptch and Gli1.

\section{Tectonics mutations-related diseases}

Non-motile ciliopathies are a group of diseases arising from the dysfunction of primary cilia including Meckel-Gruber syndrome, Joubert syndrome, Bardet-Biedl syndrome, polycystic kidney disease, Oro-facial-digital syndrome, retinitis pigmentosa, and SeniorLøken syndrome, Jeune asphyxiating thoracic dystrophy, and Leber congenital amaurosis [1, 47-49]. These ciliopathies have many characteristic features for the loss of one or more key signaling pathways. For the Shh signaling pathway-related non-motile ciliopathies, Meckel-Gruber syndrome, Joubert syndrome, Oro-facial-digital syndrome, and BardetBiedl syndrome are common. The increasing line of evidences indicates that the mutations of tectonic genes are important causes of the Shh pathway-related ciliopathies [21-29], highlighting a vital role for tectonic proteins in developmental process. Ciliopathies with tectonics mutations are discussed in more details below.

\section{Meckel-Gruber syndrome}

Meckel-Gruber syndrome, also known as dysencephaliasplanchnocystica, Gruber syndrome or Meckel syndrome, was named after the first description of this disease by German anatomist Johann Friedrich Meckel in 1822. In 1934, George Gruber reported several cases with similar phenotypes and named it 'dysencephaliasplanchnocystica' [50]. Meckel-Gruber syndrome is one kind of extremely severe and rare hereditary ciliopathy in an autosomal recessive pattern. Its incidence ranges from 1/13, 250 to 1/140, 000 live births in the world [51]. Meckel-Gruber syndrome can be easily diagnosed by its classic triad: central nervous system malformation, polydactyly and cystic renal diseases. So far, the mutations in multiple genes have been reported to cause Meckel-Gruber syndrome including B9D1, B9D2, CEP290, CC2D2A, KIF14, NPHP3, RPGRIP1L, TCTN2, TMEM67, TMEM107, TMEM216, TMEM231 genes, indicating the genetic heterogeneity of Meckel-Gruber syndrome [52]. In 2011, TCTN2 was identified as a novel MKS locus in two patients with Arab origin [23]. This suggests that TCTN2 can mediate the functional defects of cilia in Meckel-Gruber syndrome; however, how TCTN2 mutant protein interacts with down-stream proteins and causes Meckel-Gruber syndrome is still unknown.

\section{Oral-facial-digital syndrome}

Oral-facial-digital (OFD) syndrome is a group of rare heterogeneous disorders manifested as anomalies in oral cavity, face and digits. To date, more than 14 subtypes of Oral-facialdigital syndrome have been described [53-56]. Most of the OFD syndrome is transmitted in a autosomal recessive inheritance pattern except the OFD type VIII as a X-linked dominant disease [54]. OFD is characterized by tibial malformation, epicanthus, micrognathia, cystic kidney, and occipital encephalocele [22]. Those phenotypes are highly overlapped with other ciliary disorders, like Joubert syndrome. 
So far, 8 causative genes have been identified for OFD syndrome $[57,58]$. Among these genes, TCTN3 is also reported to be a causative gene of OFD syndrome. By performing the genome-wide homozygosity mapping and exome sequencing, a novel mutation was localized in the exon 11 of TCTN3 gene (c.1222C>T, p.Glu408*) in a male fetus with OFD syndrome type IV[22]. The patient presented cystic kidneys, severe skeletal dysplasia, facial dysmorphism with a lobulated tongue, and occipital encephalocele; In addition to those phenotypes, this patient also had a molar tooth sign in magnetic resonance imaging that is often observed in patients with Joubert syndrome [22]. These overlapping symptoms suggest that TCTN3 protein may execute essential multiple functions during ciliogenesis [22]. In addition, a 650653 deletion in exon 5 of TCTN3 and a missense mutation (c.940G>A, p.Gly314Arg) in TCTN3 were found to cause OFD syndrome type IV [22]. Interestingly, a more recent study showed that a mutation (c.342-2A>G, p.Gly115Lysfs*8) in TCTN1 was responsible for the phenotypes of Varadi syndrome, which is known as OFD syndrome type VI [57]. These suggest that any disruption in the functional module of cilia by TCTN1 or TCTN3 mutation can result in ciliopathies that share overlapping phenotypes.

\section{Joubert syndrome}

Joubert syndrome was first reported in 1968 by a French neurologist, Marie Joubert [59]. Joubert syndrome is a rare, autosomal recessive or X-linked recessive developmental disorder that includes cerebral vermis hypoplasia, hypotonia, ataxia, development delay, and cognitive impairment symptoms [60]. The hallmark of this disorder is known as a molar tooth sign in magnetic resonance imaging due to aplastic vermis, deep posterior interpeduncular fossa, and thickened superior cerebellar peduncles [60,61]. Joubert syndrome related disorders are a group of disorders with pathognomonic and neuroradiological features similar to Joubert syndrome and involve various organ dysfunction, mainly in brains, eyes and kidneys [61]. These disorders have been classified under the spectrum of ciliopathies. According to a recent study, about 55\% 60\% patients with Joubert syndrome are caused by the known gene mutations [62]. To date, there are about 30 genes to be associated with Joubert syndrome or Joubert syndrome related disorders (NPHP1, AHI1, ARMC9, CEP290, RPGRIP1L, TMEM67, CC2D2A, ARL13B, INPP5E, OFD1, TMEM216, CEP41, TMEM237, TCTN2, KIAA0556, KIF7, TCTN1, TMEM138, MKS1, C5ORF42, TMEM231, TCTN3, CSPP1, PDE6D, IFT172, ZNF423, TTC21B, B9D1, B9D2, and C2CD3) by target sequencing [63-65], indicating genetic heterogeneity of Joubert syndrome to a large extent.

Interestingly, three tectonic genes were among the gene spectrum that cause Joubert syndrome. Several families with Joubert syndrome were reported to have TCTN1 mutations. In 2012, A TCTN1 mutation (c.342-2A >G, p.G115KfsX8) was identified in three patients with similar phenotypes like prominent head, upturned nose, anteverted nostrils, strabismus, oculomotor apraxia, hypotonia, intellectual disability, and typical molar tooth sign [25]. By using homozygosity mapping approaches, a splice-acceptor mutation in TCTN1 (IVS1-2a>g) was found in two sisters affected with JBTS[24]. Two heterozygous pathogenic mutations in the TCTN1 gene (c.262G > A [p.D88N] and c.1718_1721delTTTG[p.V573Dfs*?]) were reported in a female child with Joubert syndrome [26]. In addition, another compound heterozygous mutation of TCTN1 c.342_2A $>$ C (a spicing mutation) and c.898C $>$ T (p.Arg300*) was reported in one male fetus showing typical molar tooth sign [66].

TCTN2 mutations (IVS10-1G>A, c.C1873T, and c.77InsG) were identified in seven patients with Joubert syndrome in two families from the Middle East region and India [21]. A compound heterozygous TCTN2 mutation (c.1117G $>$ A [p.G373R] and c.76delG[p. D26TfsX26] ) contributed to Joubert syndrome in a Caucasian male child who died at 13 months [27]. A homozygous TCTN2 mutation (c.1235-1G>A) was identified in a male patient with postaxial hexadactyly, hypotonia, nystagmus, hyperopia, ataxic gait and typical MTS on MRI[28]. 


\section{Cellular Physiology Cell Physiol Biochem 2018;50:398-409 \begin{tabular}{ll|l} 
and Biochemistry & $\begin{array}{l}\text { DOI: 10.1159/000494017 } \\
\text { Published online: 4 October } 2018\end{array}$ & $\begin{array}{l}\text { @ } 2018 \text { The Author(s). Published by S. Karger AG, Basel } \\
\text { www.karger.com/cpb }\end{array}$ \\
\hline
\end{tabular}}

Gong et al.: The Role of Tectonic Proteins in Ciliopathies

Similarly, TCTN3 mutations are also the causes of Joubert syndrome. Thomas et al. identified a novel homozygous mutation (c.940G $>$ A) in exon 8 of the TCTN3 gene in two siblings with Joubert syndrome from Turkish family, which led to a Gly314-to-Arg (G314R) substitution [22]. One male patient from a consanguineous Persian family was reported to have a splice-site sequence variant (c.853-1G>T) in exon 7 of TCTN3 by a multi-gene panel next-generation sequencing; he had a postaxial polydactyly of left foot, ataxic gait, intellectual problems, autism-like behaviors, and typical molar tooth sign.

TCTN1, TCTN2, and TCTN3 proteins interact with each other and with other proteins involved in the pathogenesis of Meckel-Gruber syndrome like Tmem216, Tmem67, Cep290, and $\mathrm{B} 9 \mathrm{~d} 1$ in the transition zone between the basal body and the ciliary axoneme of primary cilia [28]. Therefore, Joubert syndrome has a high degree of overlapping clinical features with many other ciliopathies including Meckel-Gruber syndrome, which suggests their molecular basis involved in the pathogenesis of ciliopathies may have some congruity in some ways. Compared with Joubert syndrome by other genes, frequent symptoms such as nephronophthisis, liver fibrosis, retinal dystrophy or coloboma have not been reported in patients caused by tectonic gene mutations; however, intellectual disability is more often observed in tectonic gene mutation-caused Joubert syndrome [28]. In tectonic genecausative Joubert syndrome, the defects of TCTN2 and TCTN3 lead to more severe symptoms than the defects of TCTN1 in patients with Joubert syndrome [28].

\section{Conclusions and perspectives}

Up to now, nearly 200 genes have been reported to be associated with ciliopathies [2]. Only about $50 \%$ of the genes accounting for various types of ciliopathies shows a high degree of overlapping clinical features and results from a few causative genes, which poses an increasing challenge for physicians to make the right diagnosis. As important members of spectrum of ciliopathy genes, the discovery of tectonic genes provides an opportunity to better understand the underlying molecular pathogenesis of ciliopathies. Tectonic proteins including TCTN1, TCTN2 and TCTN3, locate in the transition zone, where mainly NPHP and MKS/JBTS complexes harbor. Therefore, mutant tectonic proteins disrupt the functions of MKS/JBTS complexes and cause Meckel-Gruber syndrome, Joubert syndrome, as well as Oralfacial-digital syndrome. TCTN2, TCTN3, MKS1, B9D1, AHI1, NPHP1, NPHP4, and CC2D2A have been proved to interact with TCTN1, while TMEM67, TMEM216 and CEP290 can be the interactors of TCTN1 under some conditions [20, 21, 24, 41]. Among all those molecules,

Fig. 2. The protein interaction network of tectonic proteins. The transition zone harbors NPHP complexes and MKS complexes. AHI 1 protein belongs to the inversion compartment as the color indicated, and CEP290 are shown to be part of the NPHP complex as well as MKS complex. TCTN1 interacts with proteins including AHI 1, NPHP4, NPHP1, CEP290, B9D1,

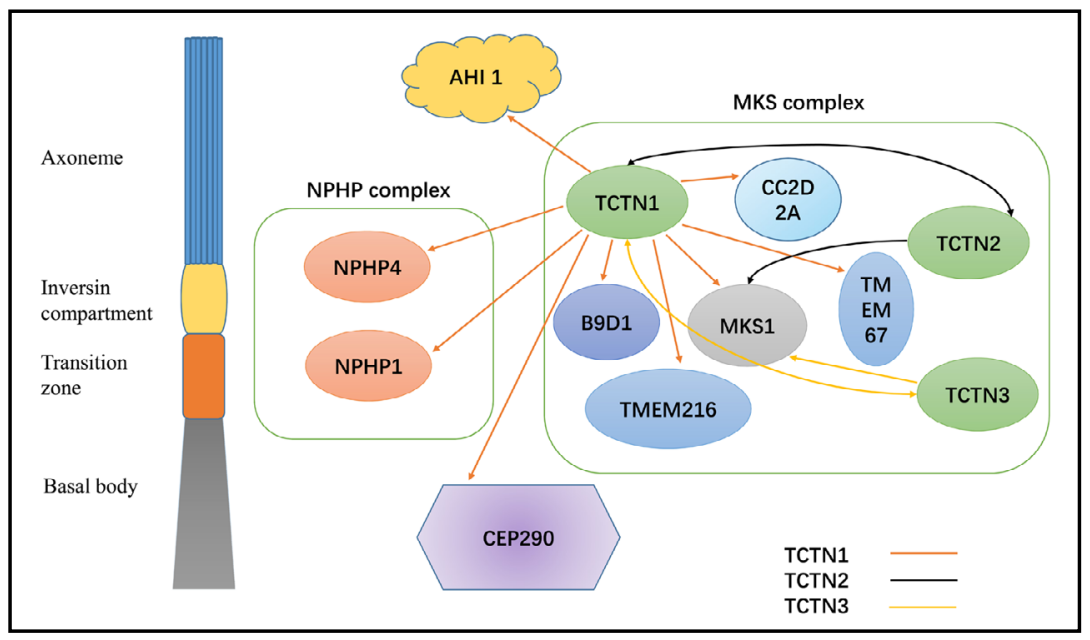
TMEM216, MKS1, CC2D2A, TMEM67, TCTN2, TCTN3. Three members in the tectonic family interact with each other. Except that, TCTN2 and TCTN3 act as interacting proteins of MKS1. 


\section{Cellular Physiology Cell Physiol Biochem 2018;50:398-409 \begin{tabular}{ll|l} 
DOI: 10.1159/000494017 & $\begin{array}{l}\text { O 2018 The Author(s). Published by S. Karger AG, Basel } \\
\text { www.karger.com/cpb }\end{array}$ \\
\hline
\end{tabular}}

Gong et al.: The Role of Tectonic Proteins in Ciliopathies

TCTN2 and TCTN3 show strongest interactions with TCTN1, which is in accordance with the fact of being in one protein family [24]. In addition, TCTN2 and TCTN3 also have interactions with MKS1 as shown in Fig. 2 [21, 41]. All three tectonic proteins have been proved to play an essential role in regulating ciliary membrane composition, ciliogenesis, neural patterning, and the Shh signaling pathway. Tectonic proteins share similar functions including neural patterning and Gli3 processing, subtle differences still can be detected. Firstly, three transgenic mice have various phenotypes that may be explained by the distinct developmental mechanisms in terms of three proteins. Secondly, unlike TCTN1 and TCTN2, TCTN3 has a unique and indispensable role in the ciliogenesis and Hh signaling pathway. Importantly, it is unknown how tectonic proteins interact with MKS/JBTS complex proteins and promote the Shh signaling pathway. If the secret veil of tectonic proteins in cilia and in the Shh signaling map is disclosed, it will be a big leap forward on the way to tackle the ciliopathies and improve life quality of patients by future gene therapy.

\section{Acknowledgements}

This work was supported by the grants from the National Natural Science Foundation of China (81570960) and National Basic Research Program of China (2013CB945400).

\section{Disclosure Statement}

The authors declare to have no interest conflicts.

\section{References}

1 Valente EM, Rosti RO, Gibbs E, Gleeson JG: Primary cilia in neurodevelopmental disorders. Nat Rev Neurol 2014;10:27-36.

-2 Reiter JF, Leroux MR: Genes and molecular pathways underpinning ciliopathies. Nat Rev Mol Cell Biol 2017;18:533-547.

3 Pan J, Snell W: The primary cilium: keeper of the key to cell division. Cell 2007;129:1255-1257.

4 Avidor-Reiss T, Ha A, Basiri ML: Transition Zone Migration: A Mechanism for Cytoplasmic Ciliogenesis and Postaxonemal Centriole Elongation. Cold Spring Harb Perspect Biol 2017;9.

-5 Lu Q Insinna C, Ott C, Stauffer J, Pintado PA, Rahajeng J, Baxa U, Walia V, Cuenca A, Hwang YS, Daar IO, Lopes S, Lippincott-Schwartz J, Jackson PK, Caplan S, Westlake CJ: Early steps in primary cilium assembly require EHD1/EHD3-dependent ciliary vesicle formation. Nat Cell Biol 2015;17:531.

6 Sorokin S: Centrioles and the formation of rudimentary cilia by fibroblasts and smooth muscle cells. J Cell Biol 1962;15:363-377.

7 Mizuno N, Taschner M, Engel BD, Lorentzen E: Structural studies of ciliary components. J Mol Biol 2012;422:163-180.

-8 Tassin AM, Lemullois M, Aubusson-Fleury A: Paramecium tetraurelia basal body structure. Cilia 2015;5:6.

-9 Gibbons IR, Grimstone AV: On flagellar structure in certain flagellates. J Biophys Biochem Cytol 1960;7:697716.

10 Ringo DL: Flagellar motion and fine structure of the flagellar apparatus in Chlamydomonas. J Cell Biol 1967;33:543-571.

11 Mitchison HM, Valente EM: Motile and non-motile cilia in human pathology: from function to phenotypes. J Pathol 2017;241:294-309.

12 Basu B, Brueckner M: Cilia multifunctional organelles at the center of vertebrate left-right asymmetry. Curr Top Dev Biol 2008;85:151-174.

13 Sedykh I, TeSlaa JJ, Tatarsky RL, Keller AN, Toops KA, Lakkaraju A, Nyholm MK, Wolman MA, Grinblat Y: Novel roles for the radial spoke head protein 9 in neural and neurosensory cilia. Sci Rep 2016;6:34437. 


\section{Cellular Physiology Cell Physiol Biochem 2018;50:398-409 \\ \begin{tabular}{ll|l} 
and Biochemistry & $\begin{array}{l}\text { DOI: 10.1159/000494017 } \\
\text { Published online: 4 October } 2018\end{array}$ & $\begin{array}{l}\text { @ } 2018 \text { The Author(s). Published by S. Karger AG, Basel } \\
\text { www.karger.com/cpb }\end{array}$ \\
\hline
\end{tabular}}

Gong et al.: The Role of Tectonic Proteins in Ciliopathies

14 Fliegauf M, Benzing T, Omran H: When cilia go bad: cilia defects and ciliopathies. Nat Rev Mol Cell Biol 2007;8:880-893.

-15 Enuka Y, Hanukoglu I, Edelheit O, Vaknine H, Hanukoglu A: Epithelial sodium channels (ENaC) are uniformly distributed on motile cilia in the oviduct and the respiratory airways. Histochem Cell Biol 2012;137:339-353.

16 Spasic M, Jacobs CR: Lengthening primary cilia enhances cellular mechanosensitivity. Eur Cell Mater 2017;33:158-168.

17 May-Simera HL, Kelley MW: Cilia, Wnt signaling, and the cytoskeleton. Cilia 2012;1:7.

18 van Reeuwijk J, Arts HH, Roepman R: Scrutinizing ciliopathies by unraveling ciliary interaction networks. Hum Mol Genet 2011;20:R149-157.

19 Berbari NF, O'Connor AK, Haycraft CJ, Yoder BK: The primary cilium as a complex signaling center. Curr Biol 2009;19:R526-535.

20 Reiter JF, Skarnes WC: Tectonic, a novel regulator of the Hedgehog pathway required for both activation and inhibition. Genes Dev 2006;20:22-27.

-21 Sang L, Miller JJ, Corbit KC, Giles RH, Brauer MJ, Otto EA, Baye LM, Wen X, Scales SJ, Kwong M, Huntzicker EG, Sfakianos MK, Sandoval W, Bazan JF, Kulkarni P, Garcia-Gonzalo FR, Seol AD, O’Toole JF, Held S, Reutter HM et al.: Mapping the NPHP-JBTS-MKS protein network reveals ciliopathy disease genes and pathways. Cell 2011;145:513-528.

22 Thomas S, Legendre M, Saunier S, Bessieres B, Alby C, Bonniere M, Toutain A, Loeuillet L, Szymanska K, Jossic F, Gaillard D, Yacoubi MT, Mougou-Zerelli S, David A, Barthez MA, Ville Y, Bole-Feysot C, Nitschke P, Lyonnet S, Munnich A et al.: TCTN3 mutations cause Mohr-Majewski syndrome. Am J Hum Genet 2012;91:372-378.

-23 Shaheen R, Faqeih E, Seidahmed MZ, Sunker A, Alali FE, AlQahtani K, Alkuraya FS: A TCTN2 mutation defines a novel Meckel Gruber syndrome locus. Hum Mutat 2011;32:573-578.

24 Garcia-Gonzalo FR, Corbit KC, Sirerol-Piquer MS, Ramaswami G, Otto EA, Noriega TR, Seol AD, Robinson JF, Bennett CL, Josifova DJ, Garcia-Verdugo JM, Katsanis N, Hildebrandt F, Reiter JF: A transition zone complex regulates mammalian ciliogenesis and ciliary membrane composition. Nat Genet 2011;43:776-784.

25 Alazami AM, Alshammari MJ, Salih MA, Alzahrani F, Hijazi H, Seidahmed MZ, Abu Safieh L, Aldosary M, Khan AO, Alkuraya FS: Molecular characterization of Joubert syndrome in Saudi Arabia. Hum Mutat 2012;33:1423-1428.

26 Gagliardi C, Brenna V, Romaniello R, Arrigoni F, Tavano A, Romani M, Valente EM, Borgatti R: Cognitive rehabilitation in a child with Joubert Syndrome: Developmental trends and adaptive changes in a single case report. Res Dev Disabil 2015;47:375-384.

-27 Juric-Sekhar G, Adkins J, Doherty D, Hevner RF: Joubert syndrome: brain and spinal cord malformations in genotyped cases and implications for neurodevelopmental functions of primary cilia. Acta Neuropathol 2012;123:695-709.

-28 Huppke P, Wegener E, Bohrer-Rabel H, Bolz HJ, Zoll B, Gartner J, Bergmann C: Tectonic gene mutations in patients with Joubert syndrome. Eur J Hum Genet 2015;23:616-620.

-29 Buke B, Canverenler E, Ipek G, Canverenler S, Akkaya H: Diagnosis of Joubert syndrome via ultrasonography. J Med Ultrason (2001) 2017;44:197-202.

30 Yang TT, Su J, Wang WJ, Craige B, Witman GB, Tsou MF, Liao JC: Superresolution Pattern Recognition Reveals the Architectural Map of the Ciliary Transition Zone. Sci Rep 2015;5:14096.

31 Wang C, Li J, Meng Q, Wang B: Three Tctn proteins are functionally conserved in the regulation of neural tube patterning and Gli3 processing but not ciliogenesis and Hedgehog signaling in the mouse. Dev Biol 2017;430:156-165.

-32 Ishikawa H, Marshall WF: Intraflagellar Transport and Ciliary Dynamics. Cold Spring Harb Perspect Biol 2017;9. pii: a021998.

33 Izawa I, Goto H, Kasahara K, Inagaki M: Current topics of functional links between primary cilia and cell cycle. Cilia 2015;4:12.

-34 Herzog W, Zeng X, Lele Z, Sonntag C, Ting JW, Chang CY, Hammerschmidt M: Adenohypophysis formation in the zebrafish and its dependence on sonic hedgehog. Dev Biol 2003;254:36-49.

-35 Rash BG, Grove EA: Patterning the dorsal telencephalon: a role for sonic hedgehog? J Neurosci 2007;27:11595-11603. 


\section{Cellular Physiology Cell Physiol Biochem 2018;50:398-409 \begin{tabular}{ll|l} 
and Biochemistry Published online: 4 October 2018 & $\begin{array}{l}\text { @ 2018 The Author(s). Published by S. Karger AG, Basel } \\
\text { www.karger.com/cpb }\end{array}$ \\
\hline
\end{tabular}}

-36 Scholpp S, Wolf O, Brand M, Lumsden A: Hedgehog signalling from the zona limitans intrathalamica orchestrates patterning of the zebrafish diencephalon. Development 2006;133:855-864.

-37 Rash BG, Grove EA: Shh and Gli3 regulate formation of the telencephalic-diencephalic junction and suppress an isthmus-like signaling source in the forebrain. Dev Biol 2011;359:242-250.

38 Currie PD, Ingham PW: Induction of a specific muscle cell type by a hedgehog-like protein in zebrafish. Nature 1996;382:452-455.

-39 Yao PJ, Petralia RS, Mattson MP: Sonic Hedgehog Signaling and Hippocampal Neuroplasticity. Trends Neurosci 2016;39:840-850.

40 Shahi MH, Rey JA, Castresana JS: The sonic hedgehog-GLI1 signaling pathway in brain tumor development. Expert Opin Ther Targets 2012;16:1227-1238.

-41 Yee LE, Garcia-Gonzalo FR, Bowie RV, Li C, Kennedy JK, Ashrafi K, Blacque OE, Leroux MR, Reiter JF: Conserved Genetic Interactions between Ciliopathy Complexes Cooperatively Support Ciliogenesis and Ciliary Signaling. PLoS Genet 2015;11:e1005627.

42 Wang B, Zhang Y, Dong H, Gong S, Wei B, Luo M, Wang H, Wu X, Liu W, Xu X, Zheng Y, Sun M: Loss of Tctn3 causes neuronal apoptosis and neural tube defects in mice. Cell Death Dis 2018;9:520.

43 Nanni L, Ming JE, Bocian M, Steinhaus K, Bianchi DW, Die-Smulders C, Giannotti A, Imaizumi K, Jones KL, Campo MD, Martin RA, Meinecke P, Pierpont ME, Robin NH, Young ID, Roessler E, Muenke M: The mutational spectrum of the sonic hedgehog gene in holoprosencephaly: SHH mutations cause a significant proportion of autosomal dominant holoprosencephaly. Hum Mol Genet 1999;8:2479-2488.

44 Zhu J, Nakamura E, Nguyen MT, Bao X, Akiyama H, Mackem S: Uncoupling Sonic hedgehog control of pattern and expansion of the developing limb bud. Dev Cell 2008;14:624-632.

-45 Choudhry Z, Rikani AA, Choudhry AM, Tariq S, Zakaria F, Asghar MW, Sarfraz MK, Haider K, Shafiq AA, Mobassarah NJ: Sonic hedgehog signalling pathway: a complex network. Ann Neurosci 2014;21:28-31.

$\$ 46$ Gorojankina T: Hedgehog signaling pathway: a novel model and molecular mechanisms of signal transduction. Cell Mol Life Sci 2016;73:1317-1332.

-47 Boldt K, Mans DA, Won J, van Reeuwijk J, Vogt A, Kinkl N, Letteboer SJ, Hicks WL, Hurd RE, Naggert JK, Texier Y, den Hollander AI, Koenekoop RK, Bennett J, Cremers FP, Gloeckner CJ, Nishina PM, Roepman R, Ueffing M: Disruption of intraflagellar protein transport in photoreceptor cilia causes Leber congenital amaurosis in humans and mice. J Clin Invest 2011;121:2169-2180.

48 Beales PL, Bland E, Tobin JL, Bacchelli C, Tuysuz B, Hill J, Rix S, Pearson CG, Kai M, Hartley J, Johnson C, Irving M, Elcioglu N, Winey M, Tada M, Scambler PJ: IFT80, which encodes a conserved intraflagellar transport protein, is mutated in Jeune asphyxiating thoracic dystrophy. Nat Genet 2007;39:727-729.

49 Baker K, Beales PL: Making sense of cilia in disease: the human ciliopathies. Am J Med Genet C Semin Med Genet 2009;151C:281-295.

50 de Silva MV, Senanayake H, Siriwardana KD: Meckel Gruber syndrome: occurrence in non-consanguineous marriages. Ceylon Med J 2004;49:30-31.

-51 Chen CP: Meckel syndrome: genetics, perinatal findings, and differential diagnosis. Taiwan J Obstet Gynecol 2007;46:9-14.

52 Barker AR, Thomas R, Dawe HR: Meckel-Gruber syndrome and the role of primary cilia in kidney, skeleton, and central nervous system development. Organogenesis 2014;10:96-107.

53 Shamseldin HE, Rajab A, Alhashem A, Shaheen R, Al-Shidi T, Alamro R, Al Harassi S, Alkuraya FS: Mutations in DDX59 implicate RNA helicase in the pathogenesis of orofaciodigital syndrome. Am J Hum Genet 2013;93:555-560.

54 Franco B, Thauvin-Robinet C: Update on oral-facial-digital syndromes (OFDS). Cilia 2016;5:12.

55 Saari J, Lovell MA, Yu HC, Bellus GA: Compound heterozygosity for a frame shift mutation and a likely pathogenic sequence variant in the planar cell polarity-ciliogenesis gene WDPCP in a girl with polysyndactyly, coarctation of the aorta, and tongue hamartomas. Am J Med Genet A 2015;167A:421-427.

-56 Chevrier V, Bruel AL, Van Dam TJ, Franco B, Lo Scalzo M, Lembo F, Audebert S, Baudelet E, Isnardon D, Bole A, Borg JP, Kuentz P, Thevenon J, Burglen L, Faivre L, Riviere JB, Huynen MA, Birnbaum D, Rosnet O, Thauvin-Robinet C: OFIP/KIAA0753 forms a complex with OFD1 and FOR20 at pericentriolar satellites and centrosomes and is mutated in one individual with oral-facial-digital syndrome. Hum Mol Genet 2016;25:497-513.

57 Al-Qattan MM, Shaheen R, Alkuraya FS: Expanding the allelic disorders linked to TCTN1 to include Varadi syndrome (Orofaciodigital syndrome type VI). Am J Med Genet A 2017;173:2439-2441. 


\section{Cellular Physiology Cell Physiol Biochem 2018;50:398-409

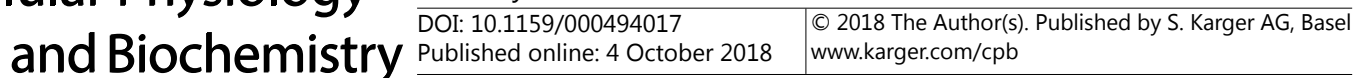 \\ Gong et al.: The Role of Tectonic Proteins in Ciliopathies}

58 Faily S, Perveen R, Urquhart J, Chandler K, Clayton-Smith J: Confirmation that mutations in DDX59 cause an autosomal recessive form of oral-facial-digital syndrome: Further delineation of the DDX59 phenotype in two new families. Eur J Med Genet 2017;60:527-532.

59 Joubert M, Eisenring JJ, Andermann F: Familial dysgenesis of the vermis: a syndrome of hyperventilation, abnormal eye movements and retardation. Neurology 1968;18:302-303.

60 Maria BL, Boltshauser E, Palmer SC, Tran TX: Clinical features and revised diagnostic criteria in Joubert syndrome. J Child Neurol 1999;14:583-590; discussion 590-581.

61 Valente EM, Brancati F, Dallapiccola B: Genotypes and phenotypes of Joubert syndrome and related disorders. Eur J Med Genet 2008;51:1-23.

62 Roosing S, Romani M, Isrie M, Rosti RO, Micalizzi A, Musaev D, Mazza T, Al-Gazali L, Altunoglu U, Boltshauser E, D’Arrigo S, De Keersmaecker B, Kayserili H, Brandenberger S, Kraoua I, Mark PR, McKanna T, Van Keirsbilck J, Moerman P, Poretti A et al.: Mutations in CEP120 cause Joubert syndrome as well as complex ciliopathy phenotypes. J Med Genet 2016;53:608-615.

63 Van De Weghe JC, Rusterholz TDS, Latour B, Grout ME, Aldinger KA, Shaheen R, Dempsey JC, Maddirevula S, Cheng YH, Phelps IG, Gesemann M, Goel H, Birk OS, Alanzi T, Rawashdeh R, Khan AO, University of Washington Center for Mendelian G, Bamshad MJ, Nickerson DA, Neuhauss SCF et al.: Mutations in ARMC9, which Encodes a Basal Body Protein, Cause Joubert Syndrome in Humans and Ciliopathy Phenotypes in Zebrafish. Am J Hum Genet 2017;101:23-36.

64 Sanders AA, de Vrieze E, Alazami AM, Alzahrani F, Malarkey EB, Sorusch N, Tebbe L, Kuhns S, van Dam TJ, Alhashem A, Tabarki B, Lu Q, Lambacher NJ, Kennedy JE, Bowie RV, Hetterschijt L, van Beersum S, van Reeuwijk J, Boldt K, Kremer H et al.: KIAA0556 is a novel ciliary basal body component mutated in Joubert syndrome. Genome Biol 2015;16:293.

65 Bachmann-Gagescu R, Dempsey JC, Phelps IG, O’Roak BJ, Knutzen DM, Rue TC, Ishak GE, Isabella CR, Gorden N, Adkins J, Boyle EA, de Lacy N, O’Day D, Alswaid A, Ramadevi AR, Lingappa L, Lourenco C, Martorell L, Garcia-Cazorla A et al.: Joubert syndrome: a model for untangling recessive disorders with extreme genetic heterogeneity. J Med Genet 2015;52:514-522.

66 Srour M, Hamdan FF, McKnight D, Davis E, Mandel H, Schwartzentruber J, Martin B, Patry L, Nassif C, Dionne-Laporte A, Ospina LH, Lemyre E, Massicotte C, Laframboise R, Maranda B, Labuda D, Decarie JC, Rypens F, Goldsher D, Fallet-Bianco C et al.: Joubert Syndrome in French Canadians and Identification of Mutations in CEP104. Am J Hum Genet 2015;97:744-753. 